\title{
Polygonal Cell Carcinoma
}

National Cancer Institute

\section{Source}

National Cancer Institute. Polygonal Cell Carcinoma. NCI Thesaurus. Code C65161.

A malignant epithelial neoplasm composed of atypical polygonal cells with a large

amount of eosinophilic cytoplasm. A representative example is the fibrolamellar hepatocellular carcinoma. 